\title{
YouTube For Two: Online Video Resources In A Student-Centered, Task-Based ESL/EFL Environment
}

Robert Hamilton, Meiji University, Tokyo, Japan

\begin{abstract}
Online technology and streaming video have the potential to generate tremendous interest and motivation in ESL/EFL students. Unfortunately, as the basis for a task-based language teaching (TBLT) program, such technology often places students in a passive position and limits interstudent communication. This paper describes a successful TBLT course at Tokyo's Meiji University, and explores some of the methodology for exploiting the motivational potential of streaming video sites, while ensuring that students use the target language both productively and receptively.
\end{abstract}

Keywords: ESL, EFL, CLT, TBLT, task-based learning, streaming video, YouTube ${ }^{\circledR}$, Meiji University

\section{INTRODUCTION}

$Q$ successful task-based curriculum for ESL/EFL learning, requires that students have a clear objective, proper motivation for reaching that objective, a group of similarly motivated peers with which to work, and the language tools and guidance necessary to fulfill their task while accessing the target language. Of the requirements on this list, student motivation is the most variable, and therefore the aspect which often gets the most attention from educators. As a solution to the perennial motivation dilemma, many classrooms are turning to the Internet. Streaming video sites like YouTube $\AA$, Dailymotion $\AA$ and Howcast ${ }^{\circledR}$ host a wealth of videos featuring native English speakers with every possible accent or dialect, and the range of topics is so vast that any student can find something of interest.

Unfortunately, generating motivation through the exploitation of online video has often come at the expense of student interaction. Computers are generally designed to be operated by one individual at a time: one keyboard, one mouse, one screen. Multimedia classrooms in modern universities often have a PC at every desk. As students are given the task of finding a certain type of video, or are presented with a link for authentic English materials, the input/feedback conduit becomes exclusively student-computer. The negotiation of meaning and the effort to produce comprehensible English within the group of peers is lost. In a supposedly student-centered, taskbased language teaching (TBLT) classroom, this can be devastating. This paper will explore a number of techniques and activities that can harness the motivational potential of streaming online video, while also fostering the type of peer interaction that is necessary for meaningful task-based English language learning.

Much of the methodology discussed in this paper was developed through trial and error while teaching in the Special Intensive English Seminar (SIES) at Meiji University in Tokyo. In this program, about 80 students are taken to a seminar house in the countryside for a week. All of the instructors on site are native English speakers, and students are required to communicate exclusively in English for the duration of the course, whether they are in or out of class at the time. The course is divided into morning and afternoon sessions, with the mornings being dedicated to grammar/vocabulary exercises based on the viewing of a movie and the exploitation of the accompanying screenplay. The afternoons are dedicated to task-based group activities. The program uses communicative language teaching (CLT), and attempts to create a learning environment that provides the necessary elements for communicative competence. According to Canale and Swain (1980), and Sauvignon (1991), these 
elements are grammatical competence, sociolinguistic competence, discourse competence and strategic competence. Brown (1994) describes a successful CLT program as incorporating all forms of communicative competence, the use of functional language for meaningful purposes, using communicative techniques to reinforce fluency and accuracy, and the requirement that students "...have to use the language, productively and receptively."

While the morning portions of the program are also student-centered, the structure and methodology (using a textbook, the use of vocabulary lists, cloze exercises, etc.) is closer to that of a traditional classroom. The afternoon sessions are almost entirely TBLT, and so the need to ensure that students are using English both productively and receptively is far more pronounced. In the various sections of the program, students work together to produce something to present to the entire student body. In one section, this product is a series of photographs; in another section, a play; other students create informative PowerPoint ${ }^{\circledR}$ presentations. Each of these activities is designed to force students to work together, using only English, in order to accomplish a fairly complicated task. These "community-based experiences" are designed to give students an opportunity to use the language that they have learned in the classroom in a more practical and meaningful context, as Montgomery and Eisenstein (1985) have shown to be extremely effective in fostering second-language acquisition.

A second difference between the morning classroom sessions and afternoon TBLT sessions is that the morning groups are streamed into classes based on their English-language competence, while the afternoon groups are completely mixed-level. This, however, is often more of a boon than the handicap that it might initially be perceived as. Students of all proficiency levels seem to produce more English during the task-based projects in these afternoon classes than they do in the morning sessions, regardless of proficiency levels. This observation is borne out in the research of Gass and Varonis (1985) which indicated advantages to grouping L2 learners of different proficiency levels, as well as Burton and Samuda (1980) and Porter (1986) which showed that not only are nonnative students unlikely to learn each other's mistakes, but they are actually able to correct each other effectively.

The TBLT portion of the course that I oversee is based on the consumption and creation of online streaming video. The course has undergone a number of changes in the eight years since I've been involved. Looking at the various incarnations can be helpful in understanding the effectiveness of various aspects. Some of these changes were minor tweaks, while others were major changes in direction, but since the beginning there has been a reliance on computer technology. The task-based group that I inherited was producing a "magazine," which required students to work together to research and write articles. While the group dynamics during the research, paper-based planning and peer editing phases of the project worked well, there was inevitably a large amount of noncommunicative time once it was time to type the articles into the computer. One student from each group would usually be using a word processor while the other students stood awkwardly and gazed over the typists' shoulders. A second problem with this particular task was that after printing, the magazine would need to be photocopied, compiled and stapled. This process was quite labour-intensive and repetitive, so students generally fell into silence while performing the task. These two low-interaction phases of the project accounted for as much as two of the six work days that we had at our disposal, meaning that about $33 \%$ of in-class time was failing to produce an acceptable level of interaction.

In order to eliminate the dead time at the end of the process, we soon turned to an online model. Each student group would contribute a group-written article or two to the class's online magazine. This was nice in that it gave the students an electronic keepsake of the course, reduced the amount of paper that was wasted, and it also took care of the non-communicative time at the end of the week. Unfortunately, when it was time to input articles, the keyboard bottleneck still prevented meaningful communication between students while a single typist entered the material into the computer for each group.

The next adjustment was the least successful in terms of TBLT, and the most meaningful breakthrough in redesigning the course. Students were told to create group blogs. Each student had their own PC and their own workstation, but all of the computers were networked so that students could easily send each other messages and edit each other's work. Students were still divided into groups, but instead of working out the details of an article before entering it into a word processor, they each completed portions of the work at their own stations, while editing and contributing to the work of others. While this eliminated the need for students to share keyboards, it also eliminated the need for them to express themselves verbally in real-time. All of the negotiation between group members was 
done in written form and mediated by the computer screen. This was a significant shortcoming, especially in a Japanese university environment, since Japanese students typically score higher on reading/writing portions of standardized English tests and lower on speaking/listening portions.

The new format, however, contained one extremely successful portion. One subproject was for each student group to produce and post a video on their blog. The planning and execution of this video portion of the blog was by far the most interactive, engaging and communicatively relevant activity of the week. Students worked together to plan the scenario for the video, practice their dialogues and roles, and finally commit it all to film (or data memory card as the case may be). Since the completed videos were uploaded to the internet, students were eager to make a good impression, and thus consciously monitored their own English and that of their group members. The completed videos were also excellent tools for students to use in self-appraisal. Many students chose to reshoot videos after seeing (and listening to) their own performances. During the reshoot, students were able to self-correct. As this one activity seemed to produce the most motivation, language production and self-monitoring from the students, the task-based portion of the course was redesigned exclusively around short, simple video clips.

This newest incarnation of the course has been extremely effective in terms of motivation, and both productive and receptive use of English. Student were first given a homework assignment in which they were to locate a "how to" video which taught them how to do something that they did not previously know. Students were told to arrive in class ready to teach others how to perform the task. This introduced students to the variety of instructional video that is available online. It also got them accustomed to the idea that while online materials would be the source of much of our discussion, class time would be largely non-digital. After students shared their new knowledge, they would be required to work in groups to plan and then create their own original "how to" video tutorial. This is the first video project of the course, and as such, it is heavily structured. Since instructional videos generally follow a step-by-step process, students don't need to think too much about format. Instead, they can focus their attention on working together to make coherent presentations. Students then proceed to practice and refine their performances before committing them to video, preferably using equipment that the students already own, such as video-capable digital cameras or mobile phones. This first video project is a practice run, and students should be able to see what areas they need to improve upon as they are viewed and critiqued by their peers.

After the instructional videos have been completed and critiqued, students can be given a second teacherguided video project, or they can be given a bit more leeway in choosing the theme of their second effort. Most students are very familiar with YouTube ${ }^{\circledR}$ and other streaming video sites. They should be able to brainstorm in groups and come up with an interesting project for the group to pursue. With this type of task-based project, instructors need to carefully monitor the activities and conversations of the various work groups. Here are also a few guidelines that have helped to make our course successful:

Minimize the number of computers in the classroom, and the length of time that computers are in use. An ideal ratio seems to be one computer for every two or three students. This allows one student at a time to control the mouse and keyboard, while requiring the other two students to communicate their intentions clearly, using the target language. Time needs to be tightly managed, though. Conversation and communication tends to taper off after the initial negotiations, and after the creative direction of the group has been solidified. As such, time in front of the computer should be limited to blocks of 20 minutes.

Require that students complete all necessary research before class. This may seem like common sense, since it is what any teacher in a regular writing or speech presentation class would have their students do. However, a great many students and teachers alike feel that since the computer is available in the classroom, then a few Google searches here and there are fine, just as long as both the searches and the results are in English. This is not the case. Having students use internet search engines in the classroom is a dangerous exercise. Firstly, the task is markedly solo, making verbal communication with other students unnecessary. Secondly, unexpected search results can easily catch a student's attention and pull them off-task. We all love to Google, but many of the sites that we end up visiting are only marginally related to the initial intent our searches. Students are no different. Classroom management is difficult enough without giving students an added temptation to depart from the task at hand. 
Incorporate technology that the students already know how to use. Teaching a class how to use a new device or piece of software takes valuable time away from the task-based project at hand. It is also an inherently teacherfocused activity, which can hinder the momentum of a good, student-centered classroom environment. In the case of creating a video, learning how to use the university's camcorder or video editing suite may be useful for a student who aspires to a career in media communication, but the purpose of the task is to activate English usage in the students, and to create an atmosphere in which students actively use English with each other. Most students already own mobile phones with built-in video capable cameras. These cameras are not going to produce any Hollywood blockbusters, but they are perfectly suitable to the production of short video clips.

No editing. This is the rule that is most likely to meet with resistance, both from instructors and students. Quite often the instructors that run a technology-based courses, and some of the students that choose to take them, already have a firm knowledge of video editing software. It is natural to want to use the skills at one's disposal in order to make a more attractive final product, however, as instructors we must keep in mind that the purpose of task-based learning is to acquire and use English, not to create professional quality video. The process of cooperating to create a video is when students acquire language. The final product is incidental to the process. A prohibition against editing accomplishes three things to make this task more meaningful. Firstly, it eliminates the editing time that would cause student conversation and communication to suffer. It also forces students to plan the video project more carefully. Since all of the dialogue and timing needs to be confirmed before the camera rolls, students are forced to cooperate well and communicate clearly in English. It also provides higher-level students with more motivation to help lower-lever students with their lines and with correcting errors, since they will all be featured in a video together. This process allows the lower-proficiency students to receive useful corrective input, while higherproficiency students enhance their critical listening skills in English by listening carefully for errors.

The how-to example discussed in this paper is but one topic that works within this framework. The important steps are 1) to first have the students research the chosen topic by browsing English-language videos for homework, 2) have students explain and discuss the contents of their chosen videos with their group members, 3) create an assignment in which the students collaborate, and use their own cameras or mobile phones to create thematically similar videos. Examples of challenging, language-producing tasks include: researching funny/interesting television commercials, then having the students create an advert for an imaginary product that they create together; looking at news items, then having students create a news report based on college events; or finding videos about unusual sports/games, then having students create and explain an original sport/game on camera. The type of project should depend on the levels and interests of your students.

These guidelines have worked very effectively within the SIES program at Meiji University. According to surveys given at the end of the course, student satisfaction in the program has reached an all-time high since making the most recent adjustments. There is also a notable increase in both receptive and productive English use within the student groups. Of course, each teacher needs to assess the classroom dynamic in order to determine a suitable balance of guidance and autonomy in order to maximize the benefits for their students.

\section{AUTHOR INFORMATION}

Robert Hamilton is a lecturer with the School Global Japanese Studies at Meiji University in Tokyo. His main areas of interest are cross-cultural influences and appropriations in Japanese and Western popular culture. He is also actively studying the use of various technologies, and their application in a language-learning classroom.

\section{REFERENCES}

1. Brown, H. D. (1994). Principals of language learning and teaching $\left(3^{\text {rd }}\right.$ ed.). Englewood Cliffs, NJ: Prentice Hall Regents.

2. Bruton, G., \& Samuda, G., Learner and teacher roles in the treatment of oral error in group work. RELC Journal, 11(3), pp. 305-325.

3. Canale, M., \& Swain, M. (1980). Theoretical bases of communicative language pedagogy. In J. Richards \& R. Scmidt (Eds.), Language and communication (pp. 2-27). London: Longman. 
4. Gass, S., \& Varonis, E. (1985). Task variation and nonnative/nonnative negotiation of meaning. In S. Gass and C. Madden (eds.), Input in second language acquisition. Rowley, MA: Newbury House.

5. Krashen, S. (1981). Second language acquisition and second language learning. Oxford: Pergamon Press.

6. Krashen S. (1982). Principles and practice in second language acquision. Oxford: Pergamon Press.

7. Montgomery, C., \& Eisentein, M. (1985). Real reality revisited: An experimental communicative course in ESL. TESOL Quarterly, 19(2), 317-334.

8. Porter, P. (1986). How learners talk to each other: Input and interaction in task-centered discussions. In R. Day (Ed.), Talking to learn: Conversation in second language acquisition. Rowley, MA: Newbury House.

9. Savignon, S.J. (1991). Communicative language teaching: State of the art. TESOL Quarterly, 25, 261-277

10. Sato, K., \& Kleinsasser, R.C. (1999). Communicative Language Teaching (CLT): Practical Understandings. The Modern Language Journal, 85(4), pp. 494-517. 


\section{NOTES}

